\title{
Media and Privacy: Case Studies In Turkey Over Hidden Camera Utilization
}

\author{
Başak Şişman, İstanbul Arel University, Turkey
}

\begin{abstract}
During the capitalist system progress, changes and transformations, that came along with the reasoning of "dominant ideology", increasingly began to extend the thought of take the communities under regulation and supervision. As a result of globalization, which is considered as a process of taking the entire World under regulation and colonization, surveillance turned out to be a stronger power with new communication devices. Panapticon, that came along with the "taking numerous individuals under surveillance and supervision in order to achieve ideal perfection" thought of Bentham, makes the legitimization of the system essential. The same apprehension is also actualized in Orwell's Big Brother as an apprehension of standardization which is constituted by a divine authority observing everybody.
\end{abstract}

In today's World, satellite systems, telephone wiretapping, taking the entire communication within the context of social media under inspection, police cameras function as members of surveillance society. Purpose of this research will be to examine the borders of private life and term of privacy in media over case incidents. Against all prohibitions, rules and ethical values, issues that frequently confronts us in media are the violations of private life. During historical process of hidden camera utilization, which is one of the indispensible occupational devices of newsmakers, there are many successful studies but also there are negative results. In this context, one of the basic debates that confronts us as being discussed in the news sector, is the issue of what is included in private space and what is not. In this research, the validity of protected area in different situations will be discussed and evaluated in the framework of occupational ethics, public personalities, public welfare, prohibitions, rules and occupational principles related with private life and within the context of hidden camera utilization.

Keywords: Privacy, media- private life, panapticon, public welfare 


\section{Introduction}

Ethical problems of journalism is one of the major debate questions of modern-day. News, journalism and ethical values are considered as a whole according to liberal pluralistic hypothesis. Rights of information is under protection by our Constitution. In democratic societies, journalists are entrusted with the task of informing and reporting news to the society with a accurate, impartial and objective journalism approach in the framework of press freedom and social responsibility. However, at this point, it is beneficial to pay attention to terms such as private living space of individuals and society benefits-profits. In today's societies, surveillance and supervision through surveillance are the leading methods of legitimization of the dominant ideology. Hidden cameras can be used in several situations as a surveillance method in order to bring freedom of press, which is one of the indispensible milestones of democracy in journalism, into force. The important thing is to know in which situations it is required to use this method.

The purpose of the study is to present the requirement of when and how to use the hidden cameras in which situations of researching - questioning journalism. Herein, freedom of press and democracy should be put emphasis on, and case studies are evaluated within the scope of public benefit and private life occupational ethics. During the research, after the completion of literature review, sample cases and comments are compiled from internet sites of newspapers and then observed.

\section{Privacy and Private Life}

In the dictionary of Turkish Linguistics Society, private stands for the thing which is not told to others, secret and privacy means the conditions of being secret, secrecy. The word "mahram(private)" that comes from the Arabic word of "haram(illicit)" has a determiner characteristic as a religious discourse in terms of application area, not because of the word being Arabic but as it defines the "violation of the borders drawn by holy orders". (Bağl1, 2011: 185). As there isn't a clear difference between the words privacy and secrecy in dictionaries, the word privacy legitimate the prevention of access, while the word secrecy evaluates the prevention of access as an extracanonical behavior in general terms. Privacy sees the behavior which seems like that doesn't threaten the others and a socially legitimate behavior as suitable, on the other hand, secrecy is a behavior that targets to hide the curiosities 
which doesn't have a mutual agreement grounds with the other members of the group and which is not legitime (Yörükhan, 2008: 131).

Victorian Law Reform Commission states that privacy is used as a meaningful and valuable word by many and the rights for protection of privacy are listed as below in their declaration titled as " Privacy in Workplace". - Not to turn into an object or property; this means not being treated like anything other than an autonomous person.- Be deprived of capacity of making relations and developing these.' In this context, privacy is considered to be a right supported by autonomy and dignity. As it can be understood from the explanations and statements, although privacy has many definitions, the essence of the term is: protection of the information about one's self from others. It is the condition of being separate and unknown from others (İçel, 2007: 94-96).

Private life predicates on the definition of "autonomous individual" term. Autonomous individual emphasize on various immunities of the individual. Assault on physical form, protection of reputation and self-esteem and various information are among these issues. In this context, the individual can prefer share or not to share any information with the media, any time they want. That issue causes serious debates in an ethical perspective nowadays. In journalism, it can't be clarified which issues are turned into news in terms of sensationalism for rating, and which issues are turned into news in the true meaning of public welfare because of the fact that "public attention" is not precisely tangible. This issue is left for good intentions and ethical values of journalists.

In today's world, “the idea for violation of private life rights for situation in which the public welfare requires it clearly" is defended. According to this approach, firstly within the democratic perspective, the right of knowing various information of public officers is given to their directors, and another issue is, the private space of several identities, who prefers to be public property with their own intentions, such as celebrities can be publicly accessible. At this point, it would be wrong to assume that the entire private space of these individuals are given up and it is open to intervention by the media. It is wrong to think that several sections of the private life is open to public just because it is not secret (Çapl1, 2002: 107-109). As a matter of fact, Video news, which are achieved by hidden cameras, which are located in hotel 
rooms, toilets, changing rooms of fashion models, "the secrecy of private life principle" is being violated.

\section{Private Life - Public Welfare in Laws and Occupational Principles}

"Freedom of Communication" is one of the basic conditions of democratic system. Journalists, who validates the freedom of communication and accepts it as a tool for right of the society in order to learn the truth, is assigned with reflection of these realities to public opinion after finding them without obliteration and exaggeration (Girgin, 2013: 445). Press Council was founded in Turkey in order to maintain a system that is based on the principles of Western democracies and to provide an auto-inspection for a respectable press with freedom. Journalists, whose ultimate purpose is to work for spreading and realization of freedom of press, are obliged to follow the Press Occupational Principles by signing Press Council Agreement (Girgin, 2008: 290). Occupational principles are principles that shows which acts are good and correct, and which are wrong to commit in order to create a respectable and trustworthy press.

Clauses of Press Occupational Principles, which are accepted by Press Council, that regards private life, states that the private lives of individuals can't be the subject of a broadcast other than the situations that is required by public benefits. In this context, Press Council doesn't discriminate celebrities who become a public property with ordinary people, it just pays attention to if there is a public benefit or not in the incident that becomes the subject of the news ( http://eski.bianet.org/diger/egitim888.htm, 24.08.2013). In this way, various information of the individual is put under protection. The decision of with whom, how, when and in which way the information will be shared is left to the individual. Individuals may prefer not to share the information. From the perspective of the journalist, who takes place on the other hand of the issue, press has freedom and society has the right for obtaining information. The ultimate duty of the journalist is to convey the correct news with the society (Şahin, 2012: 133-134). The basic problem in here is where the borders of private life starts and ends, because from time to time media members may intervene into private life space in order to use the information rights of the individuals.

It is an obligation to use the rights, which consist of the contents for freedom of communication - press, within limited borders in order to consider these rights suitable with 
law and to prevent the contradiction of the activity against laws. In this context, reality, public benefit and public interest, actuality, intellectual dependence and temperance between the subject and the expression is important.

Authenticity, which is one of the major principles of journalism, means that the news is veridical. The authenticity in here should be evaluated as not a tangible and substantial reality but as the suitability with the release approach at the moment the news is released. Even the heaviest of criticisms made must reflect the truth. Another border for journalism rights is public benefit and public interest. In the case that texts, which don't have any public interest or public benefit and don't have the news qualifications because of these reasons, harm the personal rights of a person, it should be deduced as the act is illegitimate. When a news report, which is directed to public benefit, reflects the real life incidents objectively, it becomes suitable with laws. For evaluations related with the subject, these measurements have importance. When public benefit is paid attention to, the purpose of bringing up any corruptions that occurred in any public service, is to provide carrying out the public service in best conditions. Whereas, news reports, which are released to insult public officers personally, don't match with public benefits. As there is a public interest for politicians, actors, famous sportsmen, etc., they have to meet the news reports about their private lives with tolerance. In here, especially there has to be an idea connections between authenticity, incident and the expression. An insulting report consisting of wrong discourse including offense can't be broadcast in the name of public interest (İçel : 280-281).

Suleyman Irvan put emphasis on the provisions of European Council and England Press Complaints Commission related with private life on his article titled as "Medya ve Etik (Media and Ethics)". 23 $3^{\text {rd }}$ clause of press occupational principles accepted by Europe Council Parliamentarian Council goes on like that: "The right of people for concealing private life should be respected. People, who are assigned with duties related with government, have the right of concealing their private lives as long as this doesn't affect their work within the government. For such duties, officials can't devoid of their private lives just for this reason." At this point, it is even possible to mention the private life of people who become public properties. In England, Press Complaints Commission also stated that the private life space can only be invaded if there is an issue related with the public benefit and so the borders of private life space is limited. In the framework of the decisions taken by the council, an 
individual's house, and parts of the house such as garden and additional buildings is considered to be within the borders of private life space, nearby areas or parks are excluded outside these borders. Also, hotel rooms and hospital rooms are included within the borders of private space (http://eski.bianet.org/diger/egitim888.htm, 24.08.2013). According to $20^{\text {th }}$ clause of the Constitution, the secrecy of private life has immunity.

\section{The Secrecy of Private Life}

Everybody has the right for demand of respect towards their private life and family life. The secrecy of private life and family life have immunity. "As long as there isn't a judicial decision given in due form of one or several reasons such as national security, public safety, prevention of perpetration, protection of general health and general ethical values or protection of freedom and rights of others; as long as there isn't a written order by judicial authorities in situations in which a delay would have reservations due to these reasons; nobody can be body searched, a search can't be made on their private papers and properties and none of these can't be impounded. The decision of the authorized agency is presented to approval of judge on duty within twenty four hours. Judge pronounces the decision within forty-eight hours after confiscation; otherwise, confiscation will be lifted by itself." (http://www.tbmm.gov.tr/develop/owa/anayasa.maddeler?p3=20, 23.06.2013).

As it is also stated clearly with this clause, this provision protects private life and secrets related with that from violations that may come from government or individuals. What is important in here is the assault by the government on an individual's private life and secrets related with this life, and the limitations related with these assaults.

According to $195^{\text {th }}$ clause of Turkish Criminal Law and the following clauses; under the title of "Offenses Against Privacy", the followings is punished; disclosure of contents of communication devices by person who procures these with illegitimate methods (c.195); issuing of contents of a letter or telegraph received without the approval of the sender (c.197) revealing of a secret that can cause damage with it reveal and learnt due to a requirement of official position, title, occupation or art (c.198). (Alemdar et al. 1999: 65). 
In this respect, it is stated that in case of such a revelation or declaration of such secrets occurs through press, it is not possible to take refuge in annunciation rights of the press. Turkish Newspapers Rights and Liabilities Declaration, which is observed within the scope of this study, has this statements related with rights of journalists "journalist has the right of access to all information sources and follow any incidents that defines the public life and that interests the society". However, there is also another clause about the basic principles and duties of a journalist: "Even for individuals that become public properties, the right for secrecy of the private life can't be violated without a permission for any purposes which is not directly related with the notification and intelligence rights of the society". In the attachments of Rights and Liabilities Declaration, it is clearly stated that what is essential for private life about the rightful behavior of a journalist is the public benefits. The conditions, in which the secrecy of the private life will be invalid, are listed below.

a- A research or publication about a great crime or corruption

b- A research or publication about an attitude affecting the society negatively

c- Protection of security and health of society

d- Prevention of delusion, misapprehension, making a mistake of the society as a result of the words or activities of the relevant person

Even in these conditions, the section of the private life, which becomes accessible by the society, must absolutely be directly related with the issue or it should be paid attention to if the private life of the relevant person has an effect or not on his public activities (Türkiye Gazeteciler Hak ve Sorumluluk Bildirgesi - Turkish Newspapers Rights and Liabilities Declaration, 1998: 32) .

\section{New Media Tool and Surveillance}

With the surveillance concept, globalism, new media technologies and similar concepts which started with socialization, while individuals started to record their personal data, they also started to serve as voluntary distribution body of this surveillance and inspection mechanism. Nowadays, while Martin approves surveillance which usually carries a negative meaning with meanings such as health follow-ups, keep an eye on children to keep them away from harm, Staples underlines power relations, the dominant ideology in surveillance. (Güven 2008: 173175). In "Surveillance Society", Lyon evaluates the themes such as why surveillance becomes more common this quick is a risk, privacy, power and coordination. Privacy serves the stir of 
the thoughts which consider surveillance risks. And private space scope is a subject which is always open to discussion. Emerging new surveillance mechanisms are en route to disrupt the boundary balance between private-public space. (Lyon, 2006: 18-22).

Centralized surveillance devices (panoptic spectacles) in the works of Michel Foucault aims to create individuals who look like each other that legitimates the existence of the government and constitutes a discipline system. (Maigret, 2012: 94). A mechanism which has been constituted at the point of technologies of the period that aims to get society under control, renders the society to a point where individuals are embodied in the scope of the rules designated by the dominant ideology. In this context, with inspection and surveillance, societies turn into stack of masses which do not think or produce. As it goes in Big Brother, there's an effort to make society believe to a divine power which observes everyone. This way, the mechanism is legitimated and its continuity is preserved. (Bentham and others, 2008: 118-119).

As one of the efficient surveillance mechanisms, hidden cameras are minimized and took forms which are not able to be seen in line with the developments in new media. Therefore this almost eliminates the risk of notice. Surveillance period is constantly renewing itself as a concept which exists with the socialization process, in accordance with the changes and transformations in society. Traditional surveillance techniques reveal discrepancies in time with the new surveillance technologies. As Lyon underlines, cameras and bugging devices take the place of the eye which is the main tool of the direct surveillance. The new surveillance perception provided the mechanization of many sense organs including the eyes. Akbulut points out that surveillance build is different from hidden camera usage for surveillance of inmates in panopticon with the purpose of obedience. At this point, you can make alterations, additions or removals in the recorded images and this could rule out the normalization regime. The goal in panopticon is to make the inmates who can be seen but cannot see obedient and make them useful. It's possible to mention a normalization regime here. In the surveillance carried out with hidden camera, "after the camera is placed, the person in question could be provoked, this way the desired footage is provided but the viewer only gets to watch the edited part". In this context, to take the private footage of the person is evaluated as an activity to record abnormal. (Akça ve Başer, 2011: 19-20) 


\section{Usage of Hidden Camera in Journalism in the Frame of Exemplary Events}

With the article "Everyone has the right to ask respect to their private lives" in the Inherent Rights and Tasks part of Turkish Republic Constitution dated 1982, it is underlined in previous chapters that the private life of people is secured and freedom of communication takes place in our Constitution. Mass communication devices are also obliged to transmit the data to society in accordance with social responsibility in the context of freedom of communication of individuals (Cereci, 2003: 14). At this point mass communication devices are able to act in accordance with right to know of the society in the events which are socially important and can affect the lives of the individuals directly. The usage of hidden camera is able to get into the private life spaces with methods like listening and recording telephone calls, taking photos from distance and obtaining private data and documents. At this point, to publish mistakes and corruptions in society and to inform the public is the ultimate duty of the media. Media members need to analyze well which spaces are included in the private life space of the people in question and the measure of the private space. (Çaplı: 110)

As a way to view people without their knowledge, hidden camera is first used in 1928 by journalist to record an execution. In our day, hidden camera is used by intelligence officers, polices, private detectives, blackmailers and journalists. When you take a look at many true to life examples in the World and Turkey, it can be seen that hidden camera usage is one of the indispensable profession tools. The most important point that we need to lay weight on is when, where and how it is used. Unfortunately it's not possible to address all these examples as positive ones. There are also examples originating from poor hidden camera usage beside many successful examples (http://cim.anadolu.edu.tr/pdf/2004/1130844721.pdf, 18.09.2013).

In some cases, revealing the truth is only possible by using hidden camera. The general accepted view in journalism, misleading methods shouldn't be used to gather images, sound and news. There is a obligation of an apparent public interest, public benefit in usage of these methods. On this subject, Savaş Ay - A Takimi (A Team) television programme underlines that "health of children and people" are the two most important subjects, considers using hidden camera as a shame and wants to reserve the right to use hidden camera. (Şahin, 2012 : 150-151). After the torture and violence footage which is recorded in the hidden filming carried out in Malatya 0-6 Years Kindergarten, is aired on a television channel on October 
$26^{\text {th }} 2005$, an investigation is commenced and as a result 3 of the 15 caretakers on trial faced different penalties.

(http://www.dunyabulteni.net/?aType=haber\&ArticleID=277103,05.09.2013)

After the events in Malatya Kindergarten, in his statement about the subject, President of press council, mentioned that it's inevitable to use hidden camera in circumstances which have public interest. President of Association of Journalists mentioned Rights and Responsibility Manifesto of Turkish Journalists and it's expressed in the article titled "Private Life" that "the essential is public benefit" (http://www.radikal.com.tr/turkiye/gizli_kameraya_medya_destegi-762011, 21.07.2013.). The betterments made in Malatya Kindergarten example is a clear example of the service for public interest. But when you consider the sensitivity of the reports on health and children, it doesn't justify the automatic hidden camera usage in many related subjects(Şahin, 2012: 150151).

Chris Rogers, the producer of the program which aired on English television Itv and showed the footage from the mentally challenged children's home, defends that it's necessary to use hidden camera. Authorities of that time, who made a declaration after reports, expressed that these dorms are not places where healthy children stay, but foster homes where mentally challenged children stay and taking footage via using hidden camera is the violation of the rights of these children. Other statement is also criticized taking footage with hidden camera and is expressed it is not possible to know that created scene is a work of the broadcasting corporation through editing. Rogers mentions that if there's illegal action or public interest are in question; and if there's no other way to record the evidence and indicators, they have to use this method. ( http://www.haberler.com/itv-yapimcisi-gizli-kamera-gerekliydi-2-haberi/, 12.08.2013).

By courtesy of Arena Programme of investigative journalist Uğur Dündar, places which do not value the health of the public are located and this food and health terror is tried to be prevented. After his hidden camera footage is aired on Arena programme, Şerafettin Yardimedici who was making an immoral offer to a woman who visited his office, killed himself. In newscast program Söz Fatoda, it is confirmed with hidden camera footage that Neurosurgery Department Head and Neurosurgery Expert Prof. Dr. Medical Colonel Korkut 
Alkan of Istanbul Gulhane Military Medicine Academy (GATA) is abusing his women patients and Alkan is arrested by court-martial and sent to Selimiye Prison. ( http://arsiv.sabah.com.tr/1997/03/18/f01.html,15.08.2013 ). After this two exemplary reports, the subject about the usage of hidden camera and in which cases it should be used were on agenda of Turkey for a long period. Dündar and Sahin also defended that hidden camera should be used in these events since there's no other method to reveal this kind of corruptions in investigative journalism and the public interest side of these events outweighs here.

Mark Effron says in his article Hidden Cameras: A News Executives Perspective', 'Many self appointed defenders of the public interest (most of whom work for newspapers) whould have you believe that using hidden cameras violates all journalistic principles"'(http://dlib.nyu.edu/ 20.12. 2014). In his article which is published in the September 1997 issue of Communicator Magazine, Bob Steele emphasizes that hidden camera usage have high risk and it is hard. Indeed, as long as it doesn't serve a higher purpose (such as a critical matter related to society or interference in private life...) hidden camera usage is a violation of confidentiality and protection of private life. On this subject:-Hidden camera should be used as a last resort. (After trying other methods such as other ways of interviews, observation, document and data research)-Hidden camera must be used by experience investigative journalists.-An in-depth investigation should be carried about the subject. Because, while using hidden camera, unrelated people may get into picture during filming and innocent people may suffer to reveal truth in name of society.)- Hidden camera is a good technique to gather information if it's used right and carefully. (http://www.dorduncukuvvetmedya.com/arsiv/gkam.html, 14.07.2013).

When these methods preferred, the reporter should include the reasons in his report. The footage gathered by placing hidden cameras to private spaces such as dressing rooms, toilets, etc just to obtain ratings, does not tally with media ethics. In this case, freedom of information for media and preserving the private life of the individual would clash since there could be a breach of privacy(Uzun, 2007: 100-101).

\section{Suggestions and Assessment}

In many reports on media today, we see the breach of codes of conduct. We see the subject of breach of private life and privacy in many reports, especially on tabloid press. In the scope of 
freedom of press, the main principle of the reporter is to convey information to the society by considering truth and realism concepts. Foucault considers the surveillance universe as one of the legitimatizing methods of the dominant ideology. In this context, governments apply policies to form the society according to their desires through many surveillance mechanisms and they use many surveillance methods. Wiretapping and hidden camera use is considered among these methods. Here, the reporter is responsible to maintain balance between freedom of press, the right of the public to get accurate information and public interests, private life concept. Every latent image that violates the immunity of private life or sound recordings violate the communication freedom can't be used except the events requires public interest even if they are acquired through legal ways.

When the hidden camera is used carefully and with an in-depth study by experienced reporters, as a powerful weapon of reporters, it helps to reveal many events which would provide public interest.< It's possible to see many successful examples of this in the World and Turkey but you can run across adverse cases which may even result with the suicide of people who are not even related to the event. The common ground of many experienced reporter of the media world is, use of hidden camera should be the last resort.

The hidden camera should be used in cases where the immunity of the private life and public interest is clear and required and in cases where all methods are tried and ended up with no results. The right of the public to learn truth should be carried out truthfully and the identity of the person and the social results of the case should be evaluated thoroughly. Otherwise hidden camera would not be a tool which is used to gather information in journalism, it would be a tool to serve the perception of rating and sensation of media corporations. As a journalist, emphasized, these methods should be used as "not a tool of extrajudicial execution, as a tool of self defense". But this way, the media freedom which provides functionality to democracy will happen with hidden camera usage. 


\section{References}

Akca Gursoy ve Başer Doğa.(2011). “Karanligin Yok Olusu” Gelisen Teknolojinin Gizlilik ve Mahremiyet Üzerindeki Etkileri” ,Mugla University Social Sciences Institute Magazine Bahar, Issue 26

Bagli, Mazhar. (2011). Modern Bilinç ve Mahremiyet, Istanbul: Yarın Yayinlari

Bentham, Jeremey et al. (2008). Panopticon Gözün İktidarl (Bariş Coban ve Zeynep Ozarslan translation), İstanbul, Su Yayinlari.

Cereci, Sedat. (2003). Medya Etiği, Istanbul: Metropol Yayınları.

Doğan Yayincilik. Yazılı Medya Yayin Ilkeleri.

Çapl1, Bulent. (2002). Medya ve Etik, Ankara: Imge Yayincilik

Girgin, Atilla.(2008). Gazeteciligin Temel Ilkeleri, Istanbul: Der Yayinlari.

Girgin, Atilla ve Ozay Secil.(2013). Haber Yazmak, Istanbul: Der Yayinlari.

Guven, Sevgi. (2011). 'Gözetimin Toplumsal Mesruiyeti', 3rd Section, Medya ve Mahrem, Huseyin Kose, ed.) Istanbul: Ayrıntı Yayınları.

Icel, Kayıhan. (2001). Kitle Haberlesme Hukuku, 5th Print, Istanbul: Beta Yayinlari.

Icel, KayIhan. (2007). Özel Yasam Medya ve Ceza Hukuku, Doyle Carolyn and Bagaric Mirko (Esra Demir translation) pp.91-105. , Mahremiyet Hakki: Cazip Ama Kusurlu, Ankara: Seckin Yayinlari.

Lyon, David. (2006). Gozetlenen Toplum, Gunluk Hayati Kontrol Etmek,( Gozde Soykan translation), Istanbul: Kalkedon Yayincilik.

Maigret Eric.(2012). Medya ve Iletisim Sosyolojisi, (Halime Yücel translation.), Istanbul: İletisim Yayincilik.

Sahin, Haluk. (2012). Kim Korkar Sorusturmaci Gazeteciden?, Istanbul: Say Yayinlari.

Turkiye Gazeteciler Hak ve Sorumluluk Bildirgesi

Uzun, Ruhdan.( 2007). "Iletisim Etigi" Sorunlar ve Sorumluluklar, Ankara: Gazi Universitesi Yayınlari No:8..

Yorukhan, Turhan. (2008). “Bir Iliski Duzenleme Sureci Olarak Mahremiyet”, pp. 129-179 Tisk Akademi.

\section{Internet Sources}

http://www.tbmm.gov.tr/develop/owa/anayasa.maddeler?p3=20,23.06.2013

http://www.dorduncukuvvetmedya.com/arsiv/gkam.html, 14,07.2013.

http://www.dunyabulteni.net/?aType=haber\&ArticleID=277103, 5.09.2013 
http://www.radikal.com.tr/turkiye/gizli_kameraya_medya_destegi-762011), 21.07.2013 http://arsiv.sabah.com.tr/1997/03/18/f01.html, 15.08.2013.

http://www.haberler.com/itv-yapimcisi-gizli-kamera-gerekliydi-2-haberi/), 12.08.2013. http://eski.bianet.org/diger/egitim888.htm, 24.08.2013)

http://dlib.nyu.edu/undercover/ii-hidden-cameras-news-executives-perspective-mark-effron radio-television-digital-news-association Hidden cameras: A news executive's perspective" - mark effron - radio television digital news association, 20.12.2014 cim.anadolu.edu.tr/pdf/2004/1130844721.pdf,18.09.2013.

ilef.ankara.edu.tr/akildefteri/gorsel/dosya/1046245815basin_kanunu.doc, 02.07.2013 